\title{
A BROAD-SPECIFICITY B-GLUCOSIDASE FROM A WILD TYPE OF YEAST ISOLATE AND ITS POTENTIAL USE IN FOOD INDUSTRY \\ Korish, M. ${ }^{1}$ and M. Salem ${ }^{2}$ \\ 1 Food Science \& Technology Dept., Fac. of Agric., Kafr El-Sheikh University. \\ ${ }^{2}$ Food Science \&Technology Dept., Fac. of Agric., Tanta University.
}

\begin{abstract}
A novel intracellular $\beta$-glucosidase was isolated from a wild type of yeast Trichosporon sp. Production of enzyme was stimulated with highest level of production in medium containing $1 \%$ lactose as a sole carbon source at $\mathrm{pH} 7$ and $30^{\circ} \mathrm{C}$ for $48 \mathrm{hr}$. The enzyme preparation exhibits activity towards several $\beta$-glucosidic substrates, indicating that, it has broad- specificity; furthermore the activity towards lactose hydrolysis was the highest compared with other substrates. Also, it was able to catalyze transglycosylation. Therefore it was used for milk lactose hydrolysis as well as oligosaccharides production. It has, thus potential use in food industry.
\end{abstract}

Keywords: $\beta$-Glucosidase, lactose hydrolysis, transglycosylation.

\section{INTRODUCTION}

$\beta$-Glucosidase enzymes catalyze the hydrolysis of various compounds with, $\beta$-D-glucosidic linkages (Woodward \& Wiseman, 1982 and Saha \& Bothast, 1996) as well as catalyzing the synthesis of oligosaccharides by reversal of their hydrolytic action (Hansson \& Adlercreutz, 2001; Saloheimo et al., 2002 \& Ishii-Karakasa, 2003). Accordingly these enzymes have been widely utilized in the food industries as a tool for the hydrolysis of glucosidic linkages in various food materials, such as increase in starch recovery from potatoes, extraction of essential oils and the extraction of green tea components. In the flavor industry, $\beta$ glucosidases are key enzymes in the enzymatic release of aromatic compounds from glucosidic precursors present in fruits and fermenting products (Shoseyov et al, 1990\& Gueguen et al, 1996). $\beta$-Glucosidases, generally categorized as an enzyme which hydrolyses $\beta$-(1-4) glucosidic linkage, has a wide variety of enzymatic properties, depending upon the origin and conditions under which the organism was grown(Han \& Srinivasan, 1969) $\beta$-Glucosidases are divided into three groups on the basis of substrate specificity (I) aryl- $\beta$-Glucosidases, which have a strong affinity for aryl- $\beta$ Glucosides (II) cellobiases, which hydrolyze only oligosaccharides (III) broadspecificity $\beta$-Glucosidases, which exhibit activity on many substrate types and are the most commonly observed $\beta$-Glucosidases (Rojas et al, 1995). The $\beta$ Glucosidase from the yeast Trichosporon $\mathrm{sp}$ is broad specificity type since it can hydrolyze many types of $\beta$-diglycosides while lactose is the second substrate after cellobiose, thus it can be called enzyme with $\beta$-glucosidase and $\beta$-galactosidase activity as described previously by (Nakkharat \&Haltrich, 2006). They isolated and characterized an enzyme from fungus Talaromyces 
thermophilus CBS 236.58 followed this phenomenon.Many $\beta$-glucosidases with very broad specificity have been isolated from many fungi (Copa-patino \& Broda ,1994; Gueguen et al, 1995;Kwon et al 1992;Pitson et al, 1997) According to the classification of $\beta$-glucosidases based on substrate specificity (Bhatia et al, 2000) most family 1 enzymes also show significant $\beta$ glalactosidase activity. $\beta$-Glalactosidases catalyse the hydrolysis of lactose; in addition, they were shown to catalyse transgalactosylation reaction. Both the hydrolaze and transferase activity of $\beta$-glalactosidases have recently attracted interest because of possible applications in food industry, such as production of low lactose milk and synthesis of oligosaccharides (Cruz et al,1999; Karasov et al, 2002 , Vasiljvic \& Jelen, 2003 , Nakkarat \& haltrich,2006) Hydrolysis of lactose by $\beta$-glalactosidases alleviates lactose maldigestion problems such as abdominal pain; flatulence or diarrhea which may result from the fermentation of undigested lactose by colonic bacteria with production of $\mathrm{H}_{2}, \mathrm{CH}_{4}, \mathrm{CO}_{2}$ and short-chain organic acids (Rings et al, 1994 ; Fooks et al,1999 \& Matioli et al 2001) Also the hydrolysis of lactose is industrial beneficial to overcome lactose crystallization in condensed milk and ice cream (Karasov et al 2002). Oligosaccharides synthesized by enzymes are mainly used as food additives (such as to beverage, infants milk powder, yogurts, chewing gums, and in the manufacture of candy, pastry, bread and jams because of their heat stability), for modification of the coloni microflora toward a healthy balance by increasing the gut bifidobacteria and lactobacilli at the expense of clostridia, proteolytic and Escherichia coli bacteroids. This change in the intestinal flora composition has been proposed to be responsible for the decrease of putrefactive products in the feces, for a lower blood cholesterol content, higher $\mathrm{Ca} 2+$ absorption, a smaller loss of bone tissue in ovariectomized rats and a lower incidence of colon cancer (Cruz et al,1999; Fooks et al, 1999, Sako et al, 1999, Boon et al 2000, Van Laere et al, 2000 , Albayrak \& Yang, 2002 \& Choi et al, 2003) This work presents for the first time a novel enzyme with $\beta$-glucosidase and $\beta$-glalactosidase activity produced by a newly isolated yeast strain and demonstrates its potential use in the production of low lactose milk and synthesis of oligosaccharides.

\section{MATERIALS AND METHODS}

\section{The yeast strain and culture conditions}

The yeast strain (Trichosporon sp.) used in this study was isolated and identified at Institute of Microbiology and Wine research, Gutenberg University, Mainz, Germany. The medium used for optimization of $\beta$ glucosidase production was as follows: $20 \mathrm{~g}$ Bacto yeast nitrogen base (Difco) with $1 \%(\mathrm{w} / \mathrm{v})$ carbon source dissolved in $1 \mathrm{~L}$ of $50 \mathrm{mM}$ buffer solution under studying $\mathrm{pH}$ value, media solution were filter sterilized. Erlenmeyer flasks (200-ml) containing $50 \mathrm{ml}$ of medium was inoculated and incubated at test temperature on a rotary shaker (200 rpm) for $24 \mathrm{hr}$.

\section{$\beta$-Glucosidase production}

The strain was grown in 5-liter Erlenmeyer flasks each containing $2000 \mathrm{ml}$ of the medium which was optimized (20g Bacto yeast nitrogen base; $1 \%(\mathrm{w} / \mathrm{v})$ lactose at $\mathrm{pH} 7$ and $30^{\circ} \mathrm{C}$ for $48 \mathrm{hr}$ ). Cells were harvested by centrifugation 
$2000 \mathrm{Xg}, 15 \mathrm{~min}$, washed twice with $50 \mathrm{mM}$ sodium citrate buffer $\mathrm{pH} 5$ and centrifuged again. The resultant paste was stored at $-18^{\circ} \mathrm{C}$ until used.

\section{Preparation of $\beta$-Glucosidase}

The cell paste was suspended in appropriate volume of $50 \mathrm{mM}$ sodium citrate buffer $\mathrm{pH} 5$ and homogenized with one volume of glass beads (diameter $0.5 \mathrm{~mm}$ ). Cells were disrupted by shaking in vibrating homogenizer (Vibrogen Zellmühle, E. Bühler, Tübingen, Germany.) at $4^{\circ} \mathrm{C}$ for 6 min (Mireau et al, 2000). Debris was removed by centrifugation at 20000X $\mathrm{g}$ for 30 min, supernatant was desalted by dialysis against distilled water and lyophilized. For partial purification the lyophilized preparation was dissolved in $20 \mathrm{mM}$ Tris/HCl buffer, $\mathrm{pH} 7.6$ and loaded onto a column (containing Q Sepharose Fast Flow, Pharmacia) which previously was equilibrated with 20 $\mathrm{mM}$ Tris/ $\mathrm{HCl}$ buffer, $\mathrm{pH} 7.6$ Elution was carried out with a linear gradient of $2 \mathrm{M} \mathrm{NaCl}$ in the same buffer, at a flow rate of $1 \mathrm{ml} / \mathrm{min}$. Active fractions were combined, desalted, lyophilized and used as enzyme preparation for further study.

\section{Enzyme assay}

One $\mathrm{ml}$ of $5 \%$ lactose $(0.139 \mathrm{M})$ solution or other tested saccharides in $0.05 \mathrm{M}$ phosphate buffer $\mathrm{pH} 6.5$ was mixed with the enzyme solution in total volume of $2.0 \mathrm{ml}$ and incubated at $40^{\circ} \mathrm{C}$. The reaction was stopped after $1 \mathrm{hr}$ by heating the tubes in a boiling water bath for $5 \mathrm{~min}$, One $\mathrm{ml}$ of the reaction mixture was deproteinized by adding $1.0 \mathrm{ml}$ of $5 \% \mathrm{ZnSO}_{4} 7 \mathrm{H}_{2} \mathrm{O}$ and $1 \mathrm{ml}$ of $4.5 \% \mathrm{Ba}(\mathrm{OH})_{2}$ and filtered. Glucose produced was estimated in $1 \mathrm{ml}$ of the filtrate by the glucose-oxidase method as cited by Cruz et al, 1981. With nitrophenylglucoside as substrate, the $p$-nitrophenol release at $40{ }^{\circ} \mathrm{C}$ was monitored at $400 \mathrm{~nm}$. In both cases an enzyme unit $(U)$ was defined as the amount of enzyme necessary to liberate $1 \mu \mathrm{mol}$ of the glucose or $p$ nitrophenol per min under the assay conditions (Makkar et al, 1981)

\section{Thermal stability}

The enzyme solution ( 3 units) was incubated in $50 \mathrm{mM}$ citrate buffer $\mathrm{pH} 5$ at different temperatures ranging from $4^{\circ} \mathrm{C}$ to $80^{\circ} \mathrm{C}$ for $60 \mathrm{~min}$., and then the remaining activities were determined using lactose as the substrate (Oikawa et al, 1998)

\section{pH stability}

The enzyme solution ( 3 units) was treated with various buffers at $4{ }^{\circ} \mathrm{C}$ for $3 \mathrm{~h}$., then the $\mathrm{pH}$ was readjusted to 6.5 , then the remaining activities were determined using lactose as the substrate. The following buffers $(50 \mathrm{mM})$ were used: (a) glycin / HCl, $\mathrm{pH} 2-3$, (b) citrate $\mathrm{pH} 4$ - 5, (c) sodium phosphate pH $6-7$, (b) Tris / $\mathrm{HCl} \mathrm{pH} 8$ and glycin / NaOH pH $9-10$ (Oikawa et al, 1998).

\section{Milk sample}

Milk sample was obtained from the farm of the Faculty of Agriculture,Kafr Elsheikh. It has the following composition, 3.3\% fat, $4.7 \%$ lactose, and $0.71 \%$ ash. For whole milk the sample was used without treatment. Skim milk sample was prepared by centrifuging the cold whole milk at $8000 \mathrm{Xg}$ for 30 min then the fat was removed. 


\section{Oligosaccharide synthesis}

The basic reaction mixture containing enzyme preparation ( 2 units) and $1 \mathrm{ml}$ of $250 \mathrm{mM}$ lactose at tested $\mathrm{pH}$ values and temperatures was left for $16 \mathrm{~h}$, and then boiled for $5 \mathrm{~min}$ in water bath, and centrifuged at $1000 \mathrm{X} \mathrm{g}$ for $3 \mathrm{~min}$. The supernatants were filtered through syringe filter $(0.45 \mu \mathrm{m}$ Minisart, Sartorius) and analyzed by HPLC equipped with an Aminex column HPX42A; (300 mm x $7.8 \mathrm{~mm}$ ). Twenty $\mu \mathrm{l}$ of each sample was applied onto the column and eluted with deionized water at a flow rate of $0.6 \mathrm{ml} / \mathrm{min}$. The reaction products were detected by refractive index and identified and quantitated by comparison with retention times of authentic appropriate sugars standards (Modified method of Choi et al, 2003).

\section{RESULTS AND DISCUSSION \\ Optimization of $\beta$-glucosidase production}

Since $\beta$-glucosidase properties are dependent upon the origin and conditions under which the organism was grown (Han \&Srinivasan,1969) while the nutritional and environmental factors for $\beta$-glucosidase production by the used strain was not previously known, thus the purpose of these growth studies was to determine the conditions that stimulate the enzyme production as follows:

\section{Effect of growth temperature on enzyme production.}

The strain was cultivated at a temperature range of $10-50^{\circ} \mathrm{C}$, for $24 \mathrm{hr}$ in medium containing $1 \%(\mathrm{w} / \mathrm{v})$ cellobiose as a carbon source at $\mathrm{pH} 7$ to determine the optimal temperature for enzyme production, the results were summarized in Fig 1 . The yeast was able to grow and release $\beta$-glucosidase at a wide range of temperature. The maximum enzyme yield $(5.7 \mathrm{U} / \mathrm{ml})$ was produced at $30^{\circ} \mathrm{C}$.

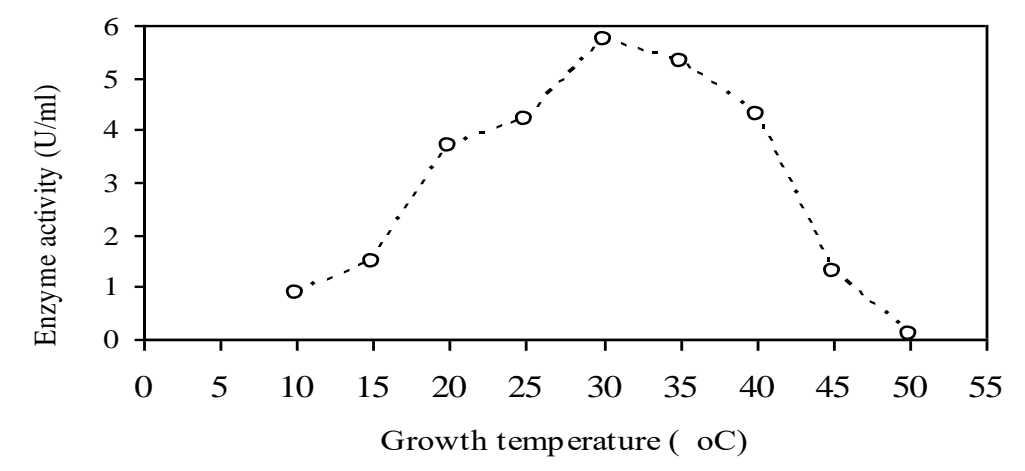

Fig 1 Effect of cultivation temperature on enzyme production.

\section{Effect of initial $\mathrm{pH}$ of culture medium on enzyme production.}

The strain was cultured at various $\mathrm{pH}$ values from 3 to 10 , for $24 \mathrm{hr}$ in medium containing cellobiose as a carbon source at $30^{\circ} \mathrm{C}$. Fig 2 shows that 
the yeast was able to grow and produce the enzyme at a broad range of $\mathrm{pH}$, while the highest enzyme yield $(5.9 \mathrm{U} / \mathrm{ml})$ was formed at $\mathrm{pH} 7$.

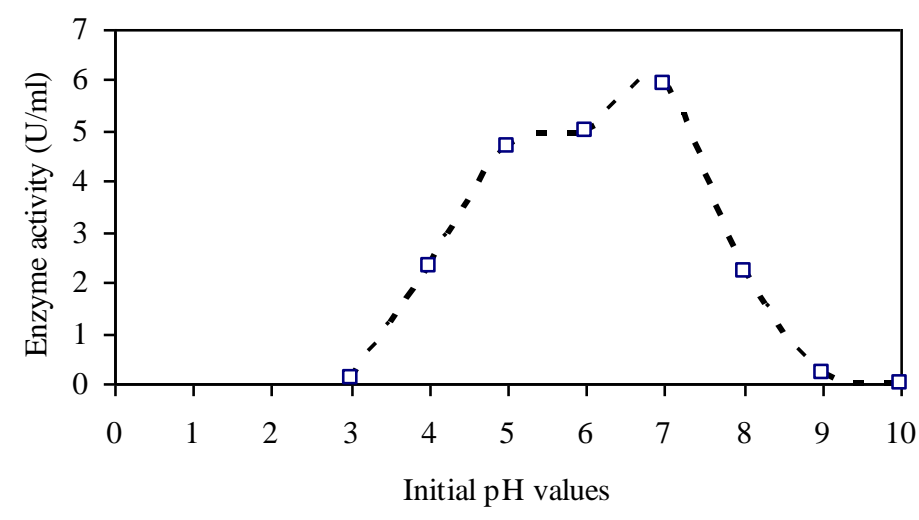

Fig 2 Effect of medium pH on enzyme production

\section{Effect of carbon source on enzyme production}

Various $\beta$-glucosidic and non- $\beta$-glucosidic carbohydrates were employed in equal concentrations of $1 \%(\mathrm{w} / \mathrm{v})$ to test their ability for inducing the formation of $\beta$-glucosidase (Table 1). In general, the yeast can utilize all tested carbohydrates with differences in the enzyme production. The formation of highest amount of $\beta$-glucosidase was induced by lactose. It could be also observed that the enzyme formation is not dependent on the kind of glucosidic bond since cellobiose, maltose and isomaltose induced the formation of approximately the same enzyme yield. These results are in agreement with the observation of other workers (Skory et al, 1996 and Riou et al, 1998) for optimization of $\beta$-glucosidaes production from other organisms.

Table 1: Effect of various carbohydrates on enzyme production.

\begin{tabular}{|l|c|}
\hline Carbon source & $\boldsymbol{\beta}$-glucosidase activity (U/mI) \\
\hline Glucose & 5.5 \\
\hline Salicin & 5.3 \\
\hline Maltose & 26.6 \\
\hline Isomaltose & 26.1 \\
\hline Raffinose & 2.1 \\
\hline Lactose & 31.0 \\
\hline Cellobiose & 26.8 \\
\hline Sucrose & 6.1 \\
\hline
\end{tabular}




\section{Time course of $\beta$-glucosidase production}

The yeast strain was cultivated under the above-identified optimal cultural conditions for $72 \mathrm{hr}$. Fig. 3 shows that the enzyme activity $(0.9 \mathrm{U} / \mathrm{ml})$ was detected after $6 \mathrm{hr}$ of incubation and increased gradually to reach its maximum $(33.45 \mathrm{U} / \mathrm{ml})$ within $48 \mathrm{hr}$ of the cultivation, and then started to decrease.

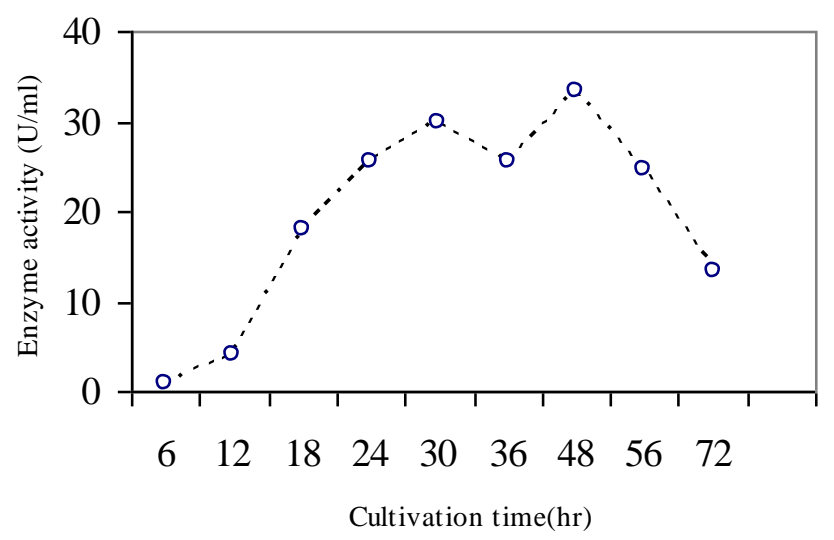

Fig 3 Effect of incubation periods on enzyme production

\section{Thermal stability}

The thermal stability experiments results are shown by Fig 4, which reveals that the enzyme preparation maintains its activity up to $35^{\circ} \mathrm{C}$ and even at 40 ${ }^{\circ} \mathrm{C}$, it retains $86.1 \%$ of its maximum activity at $45^{\circ} \mathrm{C}$ and dropped rapidly, to be completely inactivated at $80^{\circ} \mathrm{C}$.

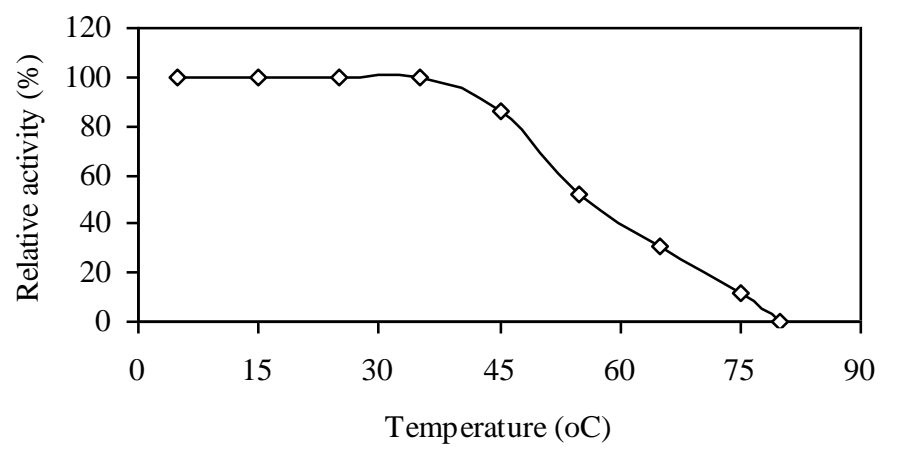

pH stability

Fig 4 Effects of temperature on the enzyme stability.

The enzyme preparation was quite stable at $\mathrm{pH} 5$ to 6 Fig 5 . The activity was gradually retarded above and below the mentioned values. 
J. Agric. Sci. Mansoura Univ., 32 (4), April, 2007

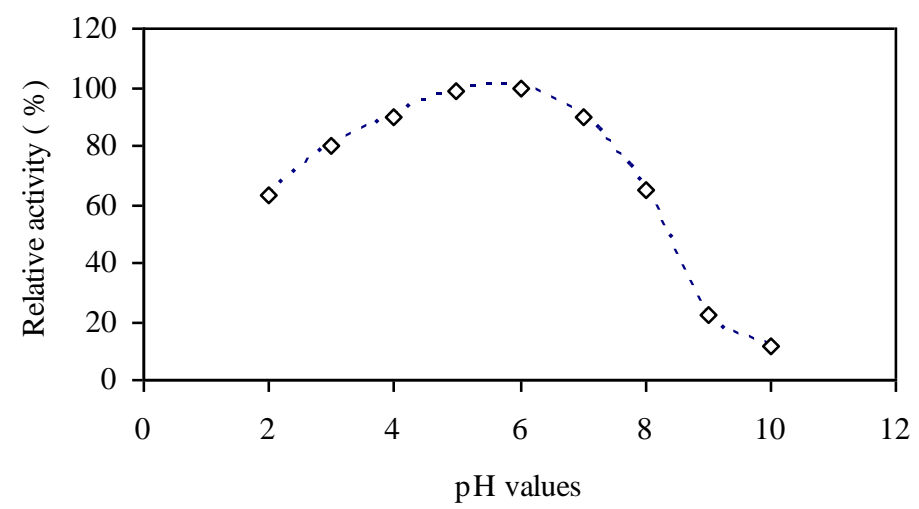

Fig 5 Effects of $\mathrm{pH}$ on the enzyme preparation stability.

\section{Substrate specificity of $\beta$-glucosidase preparation}

The enzyme preparation exhibited a broad specificity for hydrolyzing various carbohydrate types (Table 2). The rate of hydrolysis depended on the nature of aglycon moiety and the type of linkage. Highest hydrolyzing activity was observed with substrate having $\beta$-(1,4)-glucosidic linkages, such as cellobiose and lactose. The enzyme could also hydrolyze the saccharides with $\beta$ - $(1,6)$ glucosidic linkages effectively. The enzyme, however, had very little $(28.7 ; 3.2 \%$ and $0 \%)$ or no activity on sophorose, raffinose, and sucrose respectively. On the other hand, activity against polysaccharides carboxymethylcellulose (CMC) and acid-swollen avicel was not found. From the above results it can be suggested that the enzyme belonged to class " Broad substrate specificity $\beta$-glucosidase enzyme " according to the classification system based on substrate specificity (Bhatia et al, 2002). $\beta$ Glucosidases with very broad specificity have been isolated from many bacteria, yeast and fungi (Han and Srinivasan,1969;Wood and McCrae,1982 and Yan and Lin, 1997). The enzyme efficiency towards lactose hydrolysis paid our attention to do additional studies about its catalytic ability.

Table 2: Relative values rates of hydrolysis of various substrates by the enzyme preparation.

\begin{tabular}{|l|c|c|}
\hline Substrate & Type of linkage & Relative hydrolysis rate (\%) \\
\hline$p$-Nitrophenyl- $\beta$-D-glucopyranoside & $\beta \mathrm{Glc}$ & 100 \\
\hline Sucrose & $\beta, \alpha(1,2)$ & 00.0 \\
\hline Lactose & $\beta(1,4) \mathrm{Gal}$ & 119.3 \\
\hline Salicin & $\beta \mathrm{Glc}$ & 18.0 \\
\hline Raffinose & $\alpha(1,6), \beta(1,2)$ & 3.2 \\
\hline Sophorose & $\beta(1,2) \mathrm{Glc}$ & 28.7 \\
\hline Gentiobiose & $\beta(1,6) \mathrm{Glc}$ & 79.0 \\
\hline Cellobiose & $\beta(1,4) \mathrm{Glc}$ & 131 \\
\hline carboxymethylcellulose & Poly $\beta(1,4) \mathrm{Glc}$ & 00.0 \\
\hline Avicel & Poly $\beta(1,4) \mathrm{Glc}$ & 00.0 \\
\hline
\end{tabular}


Milk lactose hydrolysis.

The milk is consumed in two preferred forms skim and whole milk containing normally about $4.7 \%$ fat, thus this study aimed to define the optimum conditions for hydrolysis in both forms. The main factors, which affect on enzyme activity, include reaction $\mathrm{pH}$, reaction temperature, substrate concentration, etc. Since the substrate concentration (lactose in raw milk) is approximately stable, the study was focused on the other mentioned factors.

\section{Effect of temperature on milk lactose hydrolysis by enzyme preparation}

To define the effect of temperature on enzyme activity, the enzyme was incubated with milk at temperatures ranged from 30 to $50^{\circ} \mathrm{C}$. The results (Table 3) reveal that, the reaction was normally affected by temperature and the maximum hydrolysis yield was found at $35^{\circ} \mathrm{C}$ with both milk forms above, then a gradual fall in the hydrolysis yield was occurred. In comparison with other yeasts (Kluyveromyces fragilis and Kluyveromyces lactis) enzymes, used for lactose hydrolysis, they showed optimum temperature at $40{ }^{\circ} \mathrm{C}$ (Matioli et al, 2001 and Genari et al, 2003).

Table 3 Effect of temperatures on milk lactose hydrolysis.

\begin{tabular}{|l|c|c|}
\hline Temperature ${ }^{\circ} \mathbf{C}$ & $\begin{array}{c}\text { Lactose conversion \% } \\
\text { in whole milk }\end{array}$ & $\begin{array}{c}\text { Lactose conversion \% } \\
\text { in skim milk }\end{array}$ \\
\hline 30 & 35.90 & 36.85 \\
\hline 35 & 38.23 & 40.32 \\
\hline 40 & 30.00 & 32.13 \\
\hline 45 & 26.33 & 28.66 \\
\hline 50 & 21.61 & 23.51 \\
\hline
\end{tabular}

\section{Effect of reaction $\mathrm{pH}$ on milk lactose hydrolysis.}

The results (Table 4) indicated that the enzyme was capable to hydrolyze milk lactose at various tested $\mathrm{pH}$ values, while luckily the maximum activity was coincided with the $\mathrm{pH}$ value (6.5) of the natural milk.

Table 4: Effect of reaction pH on milk lactose hydrolysis.

\begin{tabular}{|l|c|c|}
\hline pH values & $\begin{array}{c}\text { Lactose conversion \% } \\
\text { in whole milk }\end{array}$ & $\begin{array}{c}\text { Lactose conversion \% } \\
\text { in skim milk }\end{array}$ \\
\hline 5.5 & 27.00 & 27.35 \\
\hline 6.0 & 27.80 & 29.11 \\
\hline 6.5 & 29.19 & 31.91 \\
\hline 7.0 & 26.04 & 27.43 \\
\hline 7.5 & 21.11 & 24.22 \\
\hline
\end{tabular}

This property allows using the enzyme in dairy industry without modification of milk pH. These results are in agreement with that of Makkar et al, (1981) \& Matioli et al, (2001), they reported that $\mathrm{pH} 6.5$ was the optimum value for lactose hydrolysis by the enzymes from Kluyveromyces fragilis and Lactobacillus bulgaricus. 
Time course of milk lactose hydrolysis.

Various enzyme concentrations from $(2 \mathrm{U} / \mathrm{ml}$ to $5 \mathrm{U} / \mathrm{ml})$ were used to hydrolyze the lactose in both skim and whole milk at above estimated optimum temperature and $\mathrm{pH}$ for different time periods from $1 \mathrm{hr}$ to $5 \mathrm{hr}$ to determine the minimum enzyme concentration which reduce the lactose content to be satisfactory for lactose intolerance at minimum time to prevent any change in milk properties during the treatment. The experimental results (Table 5) demonstrated that, in general the lactose hydrolysis increased by increasing of both the enzyme concentration and reaction time. The activity towards hydrolysis of skim milk was slightly more than that of whole milk at all determinations. Since it is satisfactory for lactose intolerants to hydrolyze of $90 \%$ of lactose in a products contains about $50 \mathrm{~g} / /$ lactose (Hernandez \& Asenjo, 1982). Therefore based on the experimental results (Table 5) the whole and skim milk treated with amount of enzyme $5 \mathrm{U} / \mathrm{ml}$ for $4 \mathrm{hr}$ was satisfactory for lactose intolerants. On the other hand, skim and whole milk treated with $4 \mathrm{U} / \mathrm{ml}$ for $3 \mathrm{hr}$ was readily accepted in point of view of industrial conditions according to the recommendation of Prenosil et al, 1987. They indicated that hydrolysis of $75 \%-85 \%$ of lactose in milk containing $5 \%$ lactose is industrially accepted. In comparison, with other enzymes from other organisms, the use of $3450 \mathrm{U} / \mathrm{l} \beta$-galactosidase from Kluyveromyces fragilis due to a conversion of $70 \%$ of lactose from substrate contain $5 \%(\mathrm{w} / \mathrm{v})$ lactose at pH 6.5 and $40{ }^{\circ} \mathrm{C}$ in 2 hours (Matioli et al, 2003).

Table 5 Time course of milk lactose hydrolysis.

\begin{tabular}{|c|c|c|c|c|c|c|c|c|}
\hline \multirow{3}{*}{$\begin{array}{c}\text { Time } \\
\text { (hr) }\end{array}$} & \multirow{2}{*}{\multicolumn{4}{|c|}{$\begin{array}{c}\text { Whole milk } \\
\text { Enzyme concentrations }\end{array}$}} & \multirow{2}{*}{\multicolumn{4}{|c|}{$\begin{array}{c}\text { Skim milk } \\
\text { Enzyme concentrations }\end{array}$}} \\
\hline & & & & & & & & \\
\hline & $2 \mathrm{U} / \mathrm{ml}$ & $3 \mathrm{U} / \mathrm{ml}$ & $4 \mathrm{U} / \mathrm{ml}$ & $5 \mathrm{U} / \mathrm{ml}$ & $2 \mathrm{U} / \mathrm{ml}$ & $3 \mathrm{U} / \mathrm{ml}$ & $4 \mathrm{U} / \mathrm{ml}$ & $5 \mathrm{U} / \mathrm{ml}$ \\
\hline 1 & 18.00 & 23.33 & 28.10 & 30.12 & 19.19 & 22.91 & 29.08 & 31.90 \\
\hline 2 & 37.44 & 46.16 & 56.54 & 65.67 & 38.00 & 47.51 & 57.90 & 66.60 \\
\hline 3 & 45.16 & 57.74 & 71.80 & 84.90 & 45.80 & 58.42 & 71.90 & 86.12 \\
\hline 4 & 52.88 & 69.32 & 87.42 & 92.27 & 53.00 & 70.31 & 88.61 & 93.05 \\
\hline 5 & 60.61 & 70.90 & 90.15 & 96.10 & 60.90 & 78.00 & 90.11 & 95.23 \\
\hline
\end{tabular}

\section{Oligosaccharides formation}

\section{Effect of temperature on the synthesis of oligosaccharides}

To determine the optimum temperature of oligosaccharides formation, the reaction was carried out at temperature range $20-60^{\circ} \mathrm{C}$. The results (Table 6) showed that the formation of oligosaccharides increased with the increase of temperature to reach its maximum at $40^{\circ} \mathrm{C}$ and then started to decline. These results are in agreement with the observation of Monsan \& Paul, 1995; Vasiljevic \& Jelen, 2003) they reported that the amount and the rate of oligosaccharides formation were significantly affected by the reaction temperature and $\mathrm{pH}$.

\section{Effect of $\mathrm{pH}$ on oligosaccharides formation.}

To define the optimum $\mathrm{pH}$ for oligosaccharides synthesis, the reaction $\mathrm{pH}$ was adjusted in the $\mathrm{pH}$ range $4-9$. The results (Table 7) showed that, the highest amount of oligosaccharides was formed at pH 8. It could be 
also noted that, the optimum temperature and $\mathrm{pH}$ for lactose hydrolysis by the same enzyme were $35^{\circ} \mathrm{C}$ and 6.5 (Tables 3 and 4) while in case of oligosaccharides synthesis they were shifted to be $40{ }^{\circ} \mathrm{C}$ and $\mathrm{pH} 8$, this observation was previously mentioned by Cruz et al, 1999.

Table (6): Effect of temperature on galactooligosaccharide synthesis.

\begin{tabular}{|l|l|l|l|l|}
\hline \multirow{2}{*}{$\begin{array}{l}\text { Temperature } \\
{ }^{\circ} \mathrm{C}\end{array}$} & \multicolumn{4}{|l|}{ Reaction products $(\mathrm{mM})$} \\
\cline { 2 - 5 } & Glucose & galactose & Lactose & Galactooligosaccharide \\
\hline 20 & 95.25 & 84.01 & 158.84 & 0.71 \\
\hline 30 & 152.53 & 107.05 & 118.68 & 1.21 \\
\hline 40 & 128.75 & 99.42 & 134.59 & 3.88 \\
\hline 50 & 125.12 & 95.28 & 140.64 & 1.01 \\
\hline 60 & 47.14 & 43.01 & 204.81 & 0.0 \\
\hline
\end{tabular}

Reaction conditions: substrate concentration $250 \mathrm{mM}$; Enzyme, $2 \mathrm{U} / \mathrm{ml}$ and $\mathrm{pH} 7$ for $16 \mathrm{hr}$.

Table (7): Effect of reaction pH on galactooligosaccharide synthesis.

\begin{tabular}{|l|c|c|c|c|}
\hline \multirow{2}{*}{$\begin{array}{l}\text { Reaction } \\
\text { HH }\end{array}$} & \multicolumn{4}{|c|}{ Reaction products (mM) } \\
\cline { 2 - 5 } & glucose & galactose & lactose & galactooligosaccharide \\
\hline 4 & 70.28 & 68.01 & 179.85 & 0.04 \\
\hline 5 & 116.00 & 99.05 & 138.89 & 1.80 \\
\hline 6 & 124.76 & 120.92 & 122.66 & 3.00 \\
\hline 7 & 125.11 & 118.28 & 121.59 & 4.01 \\
\hline 8 & 121.04 & 110.91 & 125.81 & 4.68 \\
\hline 9 & 49.99 & 46.85 & 199.82 & 1.62 \\
\hline
\end{tabular}

Reaction conditions: substrate concentration $250 \mathrm{mM}$; Enzyme, $2 \mathrm{U} / \mathrm{ml}$ and Temperature, $40{ }^{\circ} \mathrm{C}$ for $16 \mathrm{hr}$. The following buffers $(50 \mathrm{mM})$ were used: (a) citrate $\mathrm{pH} 4-5$, (b) sodium phosphate $\mathrm{pH} 6-7$, (c) Tris / $\mathrm{HCl}$ pH 8 and glycin / $\mathrm{NaOH}$ pH 9.

\section{Effect of substrate concentration on oligosaccharides formation.}

In order to test the influence of lactose concentration on the synthesis of the galactooligosaccharides, enzyme at concentration of $(2 \mathrm{U} / \mathrm{ml})$ incubated with various lactose concentrations. The results (Table 8) reveal that, in general this novel enzyme was able to catalyze transgalactosylation reaction with lactose as a substrate. The formation of oligosaccharides was absolutely dependent on lactose concentration, at lactose concentration lower than 200 $\mathrm{mM}$, the hydrolysis reaction was dominated, but above the mentioned concentration, the reaction was shifted towards the formation of oligosaccharides. This may be due to that, $\beta$-galactosyl groups have a higher ability of attaching to lactose than water as an acceptor at increasing lactose concentration (Iwasaki et al 1996). The formation of oligosaccharides was gradually increased with the increasing of lactose concentration to reach its maximum at $400 \mathrm{mM}$. These observations are in accordance with the findings of Boon et al, 2000, Vasilijevic \& Jelen, 2003; they reported that, initial lactose concentration is the most significant factors affecting on the oligosaccharides synthesis. Data also reveal that, the yield of oligosaccharides obtained here was lower than that obtained by other workers from other microbial enzymes (Rabiu et al, 2001, Albayrak \&yang, 
2002, \& Choi et al,2003 ). This may be due to that, oligosaccharides synthesis reaction activated by our enzyme preparation still need more optimization by studying the other parameters affecting the oligosaccharides formations such as enzyme concentration, reaction time, activators, inhibitors, etc. However, our results cleared for the first time, this novel enzyme is capable of producing oligosaccharides by transgalactosylation, which have high biological value. Also our results indicated that, the produced yield of oligosaccharides was able to enhance by optimizing the factors, which affect the reaction such as temperature, $\mathrm{pH}$ and substrate concentration.

Table (8) Effect of substrate concentration on galactooligosaccharide synthesis

\begin{tabular}{|c|c|c|c|c|}
\hline \multirow{2}{*}{$\begin{array}{c}\text { Substrate } \\
\text { concentration } \\
(\mathrm{mM})\end{array}$} & \multicolumn{4}{|c|}{ Reaction products (mM) } \\
\hline & glucose & galactose & lactose & galactooligosaccharide \\
\hline 100 & 99.87 & 98.92 & 0.0 & 0.0 \\
\hline 200 & 166.54 & 131.46 & 48.58 & 2.44 \\
\hline 300 & 224.29 & 158.8 & 98.89 & 6.84 \\
\hline 400 & 264.95 & 179.54 & 158.61 & 13.82 \\
\hline
\end{tabular}

Reaction conditions: pH 8; Enzyme, 2U/ml and Temperature, 40 oC for 16hr.
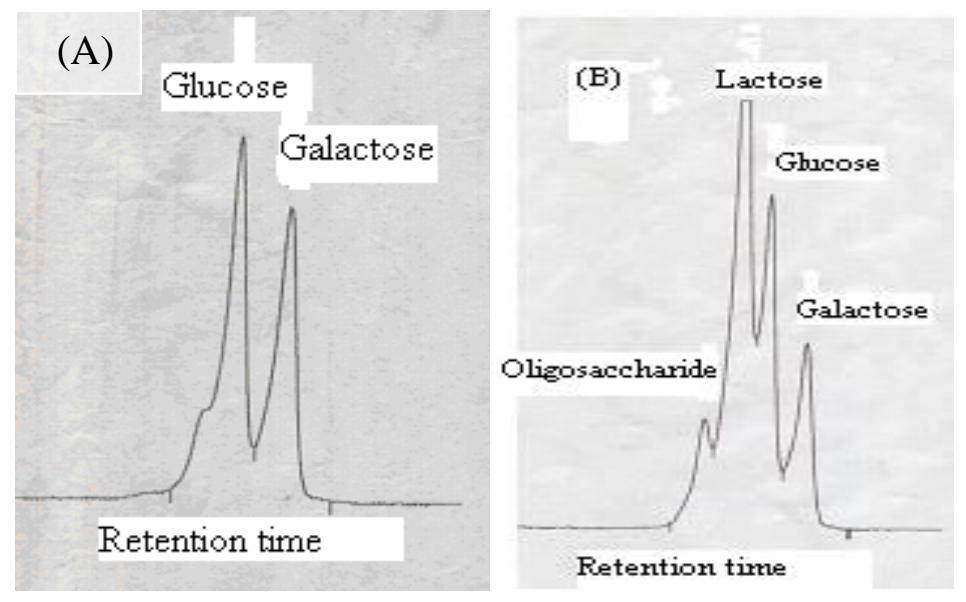

Fig (6): A typical HPLC Chromatogram showing (A) lactose hydrolysis at low lactose concentration (B) oligosaccharide formation at high lactose concentration

\section{REFERENCES}

Albayrak, N. \& Yang, S.T. (2002) Production of galactooligosaccharides from lactose by Aspergillus oryzae $\beta$-galactosidiase immobilized on cotton cloth. Biotechnology and Bioengineering 77: 8-19.

Bhatia, Y.; Mishra, S. \& Bisaria, V.S (2002) Microbial $\beta$-glucosidase: cloning, properties and applications, Critical Reviews in Biotechnology 22: $375-407$. 
Boon, M.A, Janssen, A.E.M, \& van Der Padt, A. (2000). Effects of temperature and enzyme origin on the enzymatic synthesis of oligosaccharides. Enzyme Microbial Technology 26: 271-281.

Choi, J.J; Oh,E.; Lee, Y; Suh,D.S. ;Lee,J. H.; Lee,S.;Shin, H. \& Kwon,S. (2003) Enhanced expression of the gene for $\beta$-glycosidase of Thermus caldophilus GK24 and synthesis of galacto-oligosaccharides by the enzyme. Biotechnology Applied Biochemistry 38: 131-136.

Copa-Patino, J. L., \& P. Broda. (1994) A Phanerochaete chrysosporium $\beta$ D-glucosidase $\beta$-D-xylosidase with specificity for (133)- $\beta$-D-glucan linkages. Carbohydrate Research. 253: 265-275.

Cruz, R.;Baptistela,J.C.; wosiacki,G. (1981). Microbial $\beta$-galactosidase for soymilk processing. Journal of Food science 46 (4): $1196-200$.

Cruz, R,; Cruz, V.D.A; Belote, J.G.; Khenayfes, M.O.; Dorta, C. \& Oliveria, L.H.S. (1999) Properties of a new fungal $\beta$-galactosidase with potential application in the dairy industry. Revista de Microbiologia 30: 265-271.

Fooks, L. J, Fuller, R. \& Gibson, G.R. (1999) Prebiotics,probiotics and human gut microbiology International Dairy Journal 9: 53-61.

Genari, A. N.; Passos,F.V. \& Passo,F.M.L.,(2003). Configration of a bioreactor for milk lactose hydrolysis. Journal of Dairy science 86: 2783-2789.

Gueguen, Y., P. Chemardin, A. Arnaud, \& P. Galzy. (1995). Purification and characterization of an intracellular $\beta$-glucosidase from Botrytis cinerea. Enzyme Microbial Technology 78: 900-906.

Gueguen, Y., P. Chemardin, G. Janbon, A. Arnaud, \& P. Galzy. (1996). A very efficient $\beta$-glucosidase catalyst for the hydrolysis of flavor precursors of wines and fruit juices. Journal of Agriculture and Food Chemistry 44: 2336-2340.

Han,Y.W \& Srinivasan, V. R. (1969) Purification and characterization of $\beta-$ glucosidase of Alcaligenes faecalis. Journal of Bacteriology 100: $1355-$ 1363.

Hansson, T., \& Adlercreutz, P. (2001). Enhanced transglycosylation /hydrolysis ratio of mutants of Pyrococcus furiosus $\beta$-glucosidase: effects of donor concentration, water content, and temperature on activity and selectivity in Hexanol. Biotechnology Bioengineering 75: 656-665.

Hernandez, R.; Asenjo, J. A. (1982) Production and characterization of an enzymatic hydrolysate of skim milk lactose and proteins. Journal of Food Science, Chicago 47: 1895-1898.

Ishii-Karakasa, I., (2003). Convenient analytical methods for endo-type glycosidase that acts on glycoconjugates and their application in glycotechnology. Analytical Science 9: 93-97.

Iwasaki,K.;Nakajima,M.;Nakao,S. (1996).Galacto-oligosaccharide production from lactose by an enzymatic batch reaction using $\beta$-galactosidase. Process Biochemistry 31:69-76.

Karasov, P.; Spiwok, V.; Mal, S.; Krlov,B. \& Russel, N.J.(2002) Betagalactosidase activity in psychrotrophic microorganisms and their potential use in food industry. Czech Journal of food Science 20: 43-47. 
Kwon, K. S., H. G. Kang, \& Y. C. Hah. (1992). Purification and characterization of two extracellular $\beta$-glucosidases from Aspergillus nidulans. FEMS Microbiology Letter. 97:149-154.

Makkar, H.P.S; Sharma, O.P. \& Negi, S.S.(1981). Immobilization and properties of $\beta$ - galactosidiase . Journal of Bioscience, 3: $7-16$.

Mahony, R. R. (1998) Galactosyl-oligosaccharide formation during lactose hydrolysis: A Review Food Chemistry 63:147-154.

Matioli, G.; Farias de Moraes, F. \& Zanin, G. M. (2001) Hydrolysis of lactose by betagalactosidase from Kluyveromyces fragilis: characterization of the enzyme. Acta Scientiarum, Maringa, 23: 655-659.

Matioli, G.; Farias de Moraes, F. \& Zanin, G. M. (2003). Operational stability \& kinetics of lactose hydrolysis by $\beta$-galactosidiase from Kluyveromyces fragilis. Acta Scientiarum, Maringa, 25: 7-12.

Mireau, H., Cosset, A., Maréchal-Drouard,L., Fox,T., D., Small, I., D. \& Dietrich, A. (2000). Expression of Arabidopsis thaliana Mitochondrial Alanyl-tRNA Synthetase Is Not Sufficient to Trigger Mitochondrial Import of tRNAAla in Yeast. Journal of Biological Chemistry, 275: 1329113296.

Monsan, P. \& Paul, F. (1995). Enzymatic synthesis of oligosaccharides. FEMS Microbiology Review 16: 187-192.

Nakkharat,P. \& Haltrich, D. (2006) Purification and characterization of an intracellular enzyme with $\beta$-glucosidase and $\beta$-galactosidase activity from the thermophilic fungus Talaromyces thermophilus CBS 236.58. Journal of Biotechnology 123: 304-313.

Oikawa,T.; Tsukagawa,Y. \& Soda,K. (1998) Endo- $\beta$-Glucanase Secreted by a Psychrotrophic Yeast: Purification and Characterization. Bioscience, Biotechnology and Biochemistry 62: 1751-1756.

Pitson, S. M., R. J. Seviour, \& B. M. McDougall. (1997). Purification and characterization of an extracellular $\beta$-glucosidase from the filamentous fungus Acremonium persicinum and its probable role in $\beta$-glucan degradation Enzyme Microbial Technology. 21:182-190.

Prenosil,J.E.;Stuker, E. \& Bourne, (1987). Formation of oligosaccharides during enzymatic lactose hydrolysis I. State of the art. Biotechnology and Bioengineering 30: $1019-1025$.

Rabiu, B.A; Jay,A. J. ; Gibson, G.R. \& Rastall, R.A. (2001) Synthesis and fermentation properties of novel galactooligosaccharides by $\beta-$ galactosidase from Bifidobacterium species. Applied and Environmental microbiology 67: 2526-2530.

Rings, E. H.; Van Beers, E. H.; Krasinski, S. D; Verliave, M.; Montgomery, R. K; Grand, R.L., Dekker, J.\& buler, H.A. (1994). Lactase: origin gen expression localization and function Nutrition Research 14: 775- 797

Riou, C., Salmon,J., Vallier, M., Günata, Z \& Barre, P. (1998) Purification, Characterization, and substrate specificity of a novel highly glucose-tolerant $\beta$-glucosidase from Aspergillus oryzae. Applied and Environmental Microbiology 64: 3607-3614.

Rojas, A. L. Arola, \& A. Romeu. (1995). $\beta$-Glucosidase families revealed by computer analysis of protein sequences. Biochemistry and Molecular Biology International. 35:1223-1231. 
Saha, B.C \& Bothast, R.J (1996). Production, purification and characterization of a highly glucose-tolerant novel $\beta$-glucosidase from Candida peltata. Applied and Environmental Microbiology.62: 31653170.

Saloheimo, M.; Kuja-Panula, J.;Ylösmäki,E.; Ward, M. \& Penttilä, M. (2002). Enzymatic properties and intracellular localization of the novel Trichoderma reesei $\beta$-glucosidase BGLII(CellA) Applied and Environmental Microbiology 68: 4546-4553.

Sako,T.,Matsumoto,K. \& Tanaka, R. (1999). Recent progress on research and applications of nondigestible galacto-oligosaccharides. International Dairy Journal 9: 69-80.

Shoseyov, O; Bravdo, B.A; Siegel, D.;Goldman,A.;Cohen,S.;Shosezov,L. \& Ikan. R. (1990). Immobilized endo- $\beta$-glucosidase enriches flavor of wine and passion fruit juice. Journal of Agriculture and Food Chemistry 38: 1973-1976.

Skory,C.D.,Freer,S.N.\& Bothast,R.J. (1996).Properties of an intracellular $\beta$ glucosidase purified from the cellobiose-fermenting yeast Candida wickerhamii . Applied Microbiology and Biotechnology 46: 353-359.

Van Laere, K. M.J; abee, T.; Schols, H.A.; Beldman, G. \& Voragen, A. G.J. (2000). Characterization of novel- $\beta$-galactosidase from Bifidobacterium adolescentis DSM 20083 active towards transgalactooligosaccharides. Applied and Environmental Microbiology $1379-1384$.

Vasiljevic T.,\& Jelen P, (2003). Oligosaccharide production and proteolysis during lactose hydrolysis using crude cellular extracts from lactic acid bacteria. Lait $83: 453-467$.

Woodward J.,\& Wiseman, A. (1982) Fungal and other $\beta$-glucosidases their properties and applications. Enzyme Microbial Technology 4: 73-79.

Wood, T. M., \& S. I. McCrae. (1982). Purification and some properties of the extracellular $\beta$-glucosidase of the cellulolytic fungus Trichoderma koningii. Journal of General Microbiology 128:2973-2982.

Yan, T. R., \& Lin.C. L. (1997). Purification and characterization of a glucosetolerant b $\beta$-glucosidase from Aspergillus niger CCRC 31494. Bioscience Biotechnology and Biochemistry 61:965-970.

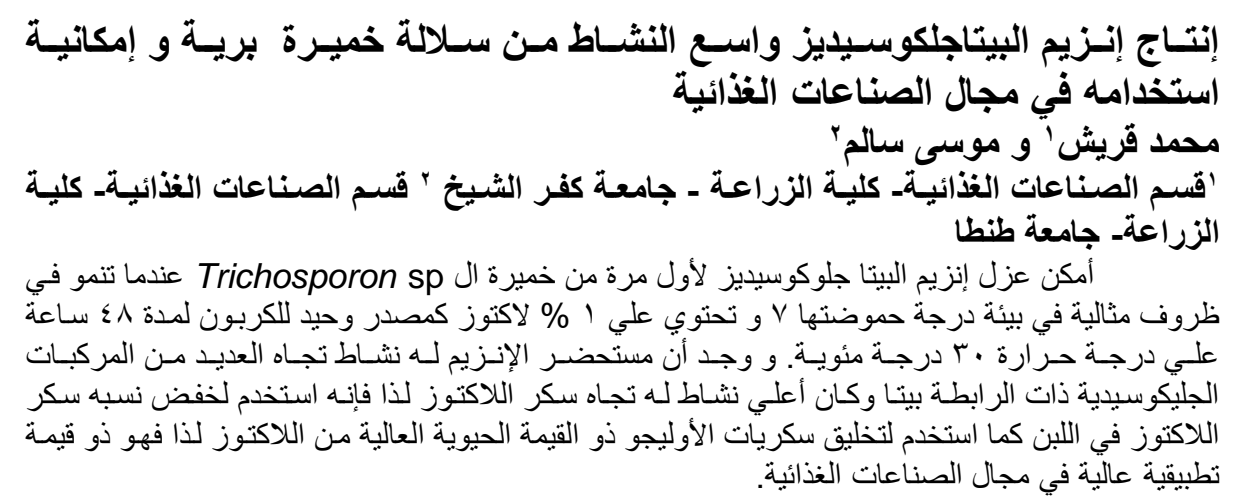

